\section{A AÇÃO RESCISÓRIA DE RESCISÓRIA NO DIREITO BRASILEIRO}

\author{
Galeno Lacerda \\ Assistente de Processo Civil na Faculdade de $\mathrm{D}_{\mathrm{i}-}$ \\ reito de P. Alegre.
}

1 - Problema interessante e curioso em nosso direito processual é o estudo e caracterização da chamada ação rescisória de rescisória, isto é, da rescisória de sentença proferida em outra ação
rescisória.

Entre nós, a rescisão, no sentido próprio, das sentenças pode ser lograda através de ação autônoma, inconfundivel com os recursos. Daí a feição peculiar que aum recursos. de legislação peculipo num tipo pesam um condicionam entença pesam um condicionamento, um relativismo, que só se extinguem com a preclusão do prazo de propositura da rescisória. Só após êsse prazo é que, a rigor, a coisa julgada material se torna absoluta, insuscetível de ser atacada e destruida. Antes disso, porérn, ela valerá si et in quantum.

E bem verdade que êsse condicionamento obedece a pressupostos. A simples possibilidade, entretanto, de ataque à sentença já constitui nota de relativismo no tocante à sua permanência.

2 - Os pressupostos da ação rescisória vêm expressos no artigo 798 do Código de Processo Civil.

São êles de dupla natureza: ou dizem com o aspecto intrínseco ou material da sentença, ou se referem a elemento extrínseco ou formal. Aquêles concernem ao conteudo da sentença - e temos o primeiro pressuposto: "quando proferida contra literal disposição de lei"; êstes, ao contrário, dizem respeito a elementos estranhos ao conteudo do provimento judicial, mas indispensáveis à próprias ao rança e estabilidade da justica - e indispensaveis a propria segupostos: "quando proferida por juiz peitado, impedido, ou incompetente ratione materiae; com ofensa à coisa julgada, e quando baseada em prova falsa".

3 - Exclui o Código, no artigo 799, a possibilidade de ação rescisória de sentença proferida noutra rescisória quando o pressuposto fôr ofensa a literal disposição de lei.
PONTES DE MIRANDA, que entre nós foi o primeiro a levantar o problema da rescisória de rescisória, critica o Código por essa restrição, e exemplifica com a hipótese de nova ofensa praticada pelo juízo rescindente. O argumento, sem dúvida, procede; mas, de outro lado, é necessário atender para "a estabilidade das relações jurídicas pela segurança dos julgados", como observa o Ministro ANIBAL FREIRE, em acórdão do Supremo Tribunal ("Jurisprudência", vol. XVIII, págs. 20-24), estabilidade que ficaria comprometida com o uso ilimitado da rescisória, fundado em contrariedade à letra da lei.

Como quer que seja, nossa lei positiva só admite a rescisória de rescisória quando os pressupostos forem estranhos ao conteudo da sentença.

Isto significa que, após a primeira rescisória, aumenta o grau de certeza quanto à permanência do comando concreto ditado pelo juiz. A coisa julgada material torna-se mais sólida. Diminuem as possibilidades de ataque e vulneração.

4 - A rescisória de rescisória dirige-se contra a sentença proferida no primeiro juízo rescindente, transformado agora em rescisório.

Dentro dos pressupostos legais, será rescindível essa sentença, quando proferida por juiz peitado, impedido, incompetente ratione materiae, com ofensa à coisa julgada ou quando fundada em prova falsa.

As hipóteses de juiz peitado, impedido ou incompetente ratione materiae, no juízo rescindente, não oferecem maior dificuldade.

As duas últimas, porém, requerem exame mais detido.

A sentença proferida no primeiro juízo rescindente só pode ofender a coisa julgada, em duas hipóteses: quando a mesma relação de direito tiver sido decidida em ação estranha ao primitivo juízo rescisório, ou quando sôbre êste já se tiver pronunciado outro juízo rescindente.

No primeiro caso, cumpre notar que só pode ser admitido esse pressuposto, quando a imputação de ofensa à coisa julgada não tiver sido decidida pelo juízo rescindente, ou, em outras palavras, não poderá ser renovada em rescisória de rescisória a questão de ofensa à coisa julgada praticada pelo primeiro juízo rescisório. Se esta questão foi resolvida pelo juízo rescindente, claro está que sôbre ela se fez nova coisa julgada, a sentença soberana que a decidiu não pode estar em conflito com o objeto de sua decisão.

O mesmo, entretanto, não ocorre quando se tratar de prova falsa. Ela tanto pode existir no juízo rescindente, como no rescisório, podendo, assim, ser renovada na rescisória de rescisória, desde que surjam novos elementos que convençam da falsidade da prova. A solução neste sentido impõe-se como norma de deontologia jurídica. 
5 - Além dêstes casos, poderá ser apreciada, na rescisória de rescisória, matéria que diga com o primitivo juízo rescisório, já julgada pelo primeiro juízo rescindente?

Vejamos as hipóteses restantes:

a) Juiz peitado - Se o juízo rescindente tiver se pronunciado contra a imputação de peita do juiz, poderá ser ela renovada? Entendemos que sim, desde que surjam novos elementos de convicção, pelo mesmo motivo invocado acima no caso de prova falsa.

b) Juiz impedido. - Da mesma forma. Trata-se de matéria. de fato, suscetível de reexame em face de novas provas.

c) Juiz incompetente "ratione materiae". - Esta hipótese, pela sua relevância, exige apreciação mais detida.

Poderá ser reaberta em rescisória de rescisória a questão da incompetência ratione materiae do primitivo juízo rescisório, já decidida e desprezada pelo primeiro juízo rescindente?

Entendemos que não.

A competência ratione materiae decorre sempre de texto legal. Ela é fixada pela interpretação da letra da lei.

Portanto, se a apreciação da incompetência ratione materiae questão extrínseca ao conteudo da sentença, questão de forma acarreta o exame da ofensa ou não da norma reguladora da competência, claro está que, tôda vez que esta matéria fôr objeto de julgamento no juízo rescindente, ela passa a constituir a própria substância da sentença neste proferida. Será forma no juízo rescisório, mas matéria no juízo rescindente.

Donde resulta que, sempre que a questão de competência ratione materiae fôr objeto de primeira ação rescisória, sôbre ela será pronunciada sentença definindo direito expresso. Logo, o reexame da mesma competência por via rescisória de rescisória dirá não mais com o aspecto formal da sentença rescindente, mas com o "jus in thesi" nela debatido, hipótese cuja apreciação nesta via é vedada em nossa lei positiva.

6 - Resta ainda examinar outra questão: Poderá ser objeto de rescisória de rescisória matéria que diga com o primeiro juízo rescisório, não julgada pelo rescindente?

Suponhamos que neste tenha sido argüida apenas ofensa a literal disposição de lei. Poderá ser proposta rescisória de rescisória, sob outro pressuposto: peita do juiz no juízo rescisório, ou incompetência ratione materiae, por exemplo?

Entendemos que a questão pode ser reaberta, não, porém, em ação rescisória de rescisória, mas em nova rescisória contra o mesmo e primitivo juízo rescisório. Não haverá, no caso, eiva alguma que se possa imputar ao juízo rescindente. O que houve foi omissão: quanto a um pedido que a êle poderia ter sido formulado, mas que quanto a um pedí em nova ação poderá ser proposto.

o foi. Logo, só em nova ação puas consequêencias: Não sendo. o assunto e de imo caso, a sentença proferida no juízo rescindente, mas rescisório, embora por outro fundamento, claro está sim a do juizo rescisố, embora a propositura da nova ação rescisória que o prazo de decadén última sentença e não daquela.

7 - Haverá limite quanto ao número de rescisórias?

- Código não as limita. A menção é genérica: "admitir-se-á O Código náro ação rescisória..." ação rescisória de sentença profé concluir que será possível esta ação,

Em conseqüência, forçoso é concluir que sera possivel esta legais, dentro dos limidesde e sempre que ocorram os pre

tes e condições acima ventilados.

8 - Estas, as breves considerações que julgamos mais inteEn álise dêste instituto novo em nosso direito processual ressantes na ana pela primeira vez admitido expressamente em nossa Novo, porque pela primeira vescassas informações da doutrina.

legislação e novo, ainda, pelas escassas iniormaçoes da doutrina.

Bem sabemos que o assunto comporta tratamento mais julgada e mais profundo, em suas relações com o problema da coisa julgada e com as exigências institucionais de segurançácícica que escapam julgados, questões de ordem

da angústia dêste trabalho.

Seja-nos permitido, porém, afirmar que a solução de nossa de positiva parece-nos feliz, porque conclia, com rassim, de forma: equilíbrio, essas exigências antinômicas, resolvendo, assim, de forma justiça legal e distributiva.

\section{RELATÓRIO E PARECER}

\section{Relator: ALCIDES DE MENDONÇA LIMA}

ora relatado, revela, apesar de sua concisão, os méritos de seu ilustrado autor, apresentando, com clareza, erudição segurança de raciocínio, exposição sistematizada e pleno conhecimenecurioso em nosso direito processual".

O Código do Processo Civil, conforme atestam seus mais autorizados comentadores, solucionou velha controvérsia, exatamente no sentido de saber-se se deve ou não ser admitida a rescisória de rescisória. 
Esta questão entre os nossos juristas não é nova, não tendo PONTES DE MIRANDA a primazia em argüí-la. Já PIMENTA BUENO e M. I. CARVALHO DE MENDONÇA focaram a tese, em sua generalidade, contrários à orientação atualmente seguida pelo Código do Processo Civil. CARPENTER também se preocupou com o problema, in "Manual de Paula Lacerda". JORGE AMERICANO, na sua monografia, escreveu igualmente sôbre o assunto em tela, desfavoràvelmente (pag. 118, n. 5), para, nos seus "Comentários ao Código do Processo Civil", aderir ao ponto de vista do diploma vigente, cedendo à argumentação da corrente que lhe era oposta (vol. 3., pág. 377). Modernamente, além dos intérpretes, pròpriamente ditos, do Código, o jovem jurista paulista LUIS EULÁLIO VIDIGAL aborda a matéria, si bem que suscintamente, no item n. ${ }^{\circ} 147$, de sua excelente monografia "Ação Rescisória dos Julgados", edição Saraiva, 1.948.

Antes da vigência do Código do Processo Civil nacional, quando os diplomas regionais eram omissos sôbre êste ponto, a doutrina entendia que a rescisória de rescisória sòmente podia ser negada quando houvesse expressa disposição de lei em contrário, como acontece no Direito Francês (art. 503) e no Direito Italiano (art. 403)

Hodiernamente, porém, ao invés do que sucedeu com outras matérias, que o legislador do Código deixou em aberto, com larga margem para discussões acadêmicas e disputas forenses, não tomando partido lamentàvelmente, como seria de desejar-se para extinguir inúmeros litígios individuais - o nosso diploma adjetivo adotou uma das correntes, filiando-se, exatamente, àquela que, segundo o tópico final da tese, "concilia, com razoável dose de equilíbrio, essas exigências antinômicas, resolvendo, assim, de forma satisfatória para - caso, o eterno conflito entre os postulados da justiça legal e distributiva".

As conclusões da tese em julgamento são exatas e bem se coadunam com o espírito que preside o Código vigente, que, entre as duas teorias sôbre a causa petendi - a da SUBSTANCTACÃO e a da INDIVIDUACÃO - adotou a primeira, pela qual a coisa julgada abrange círculo muito menor do que a última. Por conseguinte, há mais ensejo de renovação do mesmo pedido. As restrições são limitadas quanto aos efeitos da coisa julgada, havendo oportunidade para nova tentativa do autor.

O que não pode haver, evidentemente, é a renovação, na rescisória de rescisória, dos mesmos motivos já decididos pelo juízo rescindente, salvo os de prova falsa e de ser o juiz peitado, impedido ou incompetente ranione materiae, como bem salienta o douto autor

(*) Codigo Italiano anterior - art. 509
Sóbre êste último caso, procede, à saciedade, a exposição ha tese relativa a incompetência ratione materiae do juízo rescisório da tese relativa à incompetência ratione materiae do juízo

já decidida e desprezada pelo primeiro juízo rescindente.

Finalmente, merece acolhida a solução apontada no item da tese, pois, realmente, na hipótese formulada não se trata de rescisória de rescisória, mas, tão sòmente, de uma outra, de uma nova açâo rescisória, de vez que os pontos então atacados não foram vulação rescisoria, de atingidos pela anterior rescisória, pois a coisa julgada nerados, nem atingidos pela anterior rescisória, po primitiva rescisória. sòmente se consolidou quanto à parte objeto da primitiva rescisoria. Não se pode pretender rescindir aquilo que não foi deliberado ou decidido pela rescisória. Será o primeiro ataque ao julgado quanto do ponto invocado, cabendo, assim, uma nova rescisória, indepenao ponto invocado, cabé até mesmo, simultânea.

\section{CON C L U S Ã O}

Somos, portanto, de parecer que a tese proposta deve ser aproa pois reflete, plenamente, o sentido de nosso Código do Processo Civil e se harmoniza com as regras fundamentais que regem o cesso Civil e se harmón julgada, sendo de o rescisória e, mormente, da coisa julgada, senaneira lonvar a originalidade da colaboração, pois são aflorados, de maneira inédita em nossa literatura jurídica, os diversos pontos da questão, inédita menos com a especificação, análise e discussão em separado de pelo menos com a especificaçao, analise e discussádio às finalidades do Congresso.

\section{DEBATES EM PLENÁRIO}

O SR. PRESIDENTE - Julio Cesar Bonazzola

Vamos prosseguir com o terceiro tema da Ordem do Dia.

Tese: "A ação rescisória de rescisória no direito brasileiro", de autoria do Dr. Galeno Lacerda. É relator o professor Alcides de Mendonça Lima, a quem dou a palavra.

O SR. ALCIDES DE MENDONÇA LIMA - O autor em interessante trabalho, apesar da sua concisão, lança muito bem o pepois de indicar como atualmente, pelo Código de Processo Civil nacional de 1940 , se admite expressamente a ação rescisória de rescisória, resolvendo velha controvérsia de ordem doutrinária ria de rescisoria, rasos permitidos pelo nosso vigente diploma processual. Mostra, por conseguinte, que a acão rescisória de rescisória é permitida de acôrdo com o artigo 799 do Código de Processo Civil, quando proferida a sentença por Juiz peitado, impedido ou incompetente, "ratione materiae", com ofensa 10 - R. D. - $2 .^{\circ}$ Vol. 
à cousa julgada e quando fundada em falsa prova. Fica por con seguinte, afastada expressamente pelo nosso Código de Processo Civil a hipótese da rescisória de rescisória, quando houver violação de dispositivo expresso de lei.

As hipóteses especificadas no Código, como já disse, estão estudadas detalhadamente, analizados os casos do juiz peitado e do juiz impedido e do juiz incompetente "ratione materiae".

Quanto ao juiz peitado ou ao juiz impedido não há, pràticamente, dificuldade em se admitir a ação rescisória de rescisória, pois desde que fique provado que um juiz estava peitado ou impedido de funcionar, a ação deve ser naturalmente julgada procedente. Entretanto, quanto ao juiz incompetente "ratione materiae" o autor faz uma distinção interessante. Diz êle que poderá ser reaberta na rescisória de rescisória a questão da incompetencia "ratione materiae" do primitivo juiz rescisório, já decidida e desprezada pelo primeiro juiz rescidente. Entendemos que não. A competência "ratione materiae" decorre sempre do texto legal. Ela é implícita pela interpretação da lei. Portanto, se a apreciação da competência "ratione materiae", extrínseca ao conteúdo da sentença, questão de forma, aguarda o exame da ofensa ou não da norma reguladora da competência, claro está que tôda vez que esta matéria fôr objeto de julgamento no juízo rescidente, ela passa a constituir a própria substância da sentença neste proferida, será forma em juízo rescisório, mas matéria em juízo rescidente. Por conseguinte, o autor conclui muito bem: se o tribunal, ao julgar uma ação rescisória, entende que o juiz tenha competência "ratione materiae", não póde ser objeto de nova rescisória, porque neste ponto estabelece-se, consolida-se o caso julgado, donde resulta, conclúi o autor, neste ponto, que sempre que a questão de competência fôr objeto de primeira ação rescisória, sôbre ela será pronunciada sentença definida.

Finalmente, o autor expõe a hipótese de não ter sido invocado um dos motivos na primeira rescisória, ficando aberta a questão para a propositura de uma nova rescisória. Entende o autor muito bem que, neste caso, se não foi argüido um dos motivos que a lei permite para ser proposto um julgamento rescisório, êsse motivo não alegado pode ser argüido, não na rescisória, mas, diz bem o autor, numa nova rescisória, porque não se trata de rescindir um tato já objeto do Judiciário, mas nova alegação, uma alegação que ainda não foi produzida em pretório, uma alegação que ainda subsiste, naturalmente condicionada ao qüinqüênio da prescrição, se houver tempo de ser alegado, pela primeira vez, um motivo ainda não argüido na primeira rescisória. O Código, como reconhece o autor, é expresso, não limita o número de rescisórias, as recisórias são infinitas, dentro do qüinqüênio.
Por conseguinte, a única impossibilidade seria uma questão de tempo, mas se houvesse a possibilidade de propor tantas rescisórias tempo, mas síveis, o Código não faz nenhuma limitação.

Esta, em síntese, a tese.

Eu exporei agora neste douto Congresso, o parecer que me coube redigir.

$$
\text { (Lê o Parecer, mas o interrompe a certa altura) }
$$

O SR. ALCIDES DE MENDONÇA LIMA - Vou abrir um parêntesis no meu relatório para citar um caso interessante, menparentesis nendonça e que deu lugar a uma observacionado por Carvalho de Mendonça e que deu lugar a unta o seguinte: ção de Jorge Americano. Carvalho de Mendonça conta o seguinte:

Em determinada época, em São Paulo, os substitutos dos juizes eram nomeados por períodos, de modo que havia substituto para um ano e substituto para o imediato, e outro para o novo, posterior. Quando a substituição cabia aos juízes posteriores, o vindouro não podia ter jurisdição na causa. Por qualquer circunstância, que êle não explica, numa determinada causa funcionou um juiz durante o período já do outro.

Outor pretendeu, por via da ação rescisória, anular a sentença não conseguiu, apesar de haver, provado, tempos depois, que o e não conseguiu, apesar de faltava-lhe jurisdição para o caso. O Professor Carvalho de Mendonça que entendia que não se devia Professor Carvaló de rescisória, opinava, e era esta a expressão admitir a rescisória de "a decisão foi dura, mas tinha de ser assim, do grande jurista, que "a decisão fol dura, mas tinha de de um julporque não se podia violar, transgredir a imutabilidade de um jul-gado em ação rescisória." Jorge Americano, glosando a observação de Carvalho de Mendonça, diz que o autor, tendo sido apressado, proCarvalho de pondo ação sem os elementos necessários, não era um titular do Direito, mas sim um revolta rescisória de rescisória.

O SR PRESTDENTF - Vou submeter à votaç̃o. Os que estão de acôrdo com a tese, queiram ficar sentados. (Pausa). Aprovada. (Palmas). 